\title{
Perspectives of Exchange Students on the Role of Classroom Technology: A Law of Diminishing Returns?
}

\author{
Barry J. Griffiths \\ Department of Mathematics, University of Central Florida, USA
}

\begin{abstract}
Technology in the classroom has grown both in its usage and as a research topic to the extent that there are entire journals devoted to the topic. Distance learning was once considered to be the preserve of lesser institutions, but has now become common at many leading universities, and this trend shows no sign of abating. Many now question whether the traditional lecture format, and indeed the need for a campus with its expensive maintenance, will survive given that computerized technology now allows students to receive instruction from wherever they are located.

This paper considers a new perspective by seeking the views of current and former exchange students from the United States and the United Kingdom. Data was collected by interviewing twelve students representing eight universities in the two countries, and an analysis was conducted using phenomenological principles. While attitudes varied, the general feeling seemed to be that using technology to teach a class offered diminishing returns, to the point where participants were almost uniformly against the notion of completely online courses.
\end{abstract}

\section{Introduction}

The appropriate role of technology in higher education is one being debated with vigor on both sides of the Atlantic, with proponents and skeptics spanning the full spectrum between a full embrace of the digital age and outright hostility. Enthusiasts will point to the fact that technology has always played a role in education, from the widespread dissemination of books and the use of blackboards and pencils, through to the $20^{\text {th }}$ century when radio and television became new mediums for teaching and learning. The role of the Internet is therefore viewed as being part of a natural progression in educational instruction, and the increasing popularity of distance education and computer-based learning software is viewed as symptomatic of the irresistible role of classroom technology. In a study encompassing academics from institutions in North America, Europe, and Asia, Glenn [1] found that more than two-thirds of those surveyed worked at universities offering online courses.

While those in favor of its increased usage can point to the fact that advances in technology have always been opposed by a large number of those working in the educational sector, which by and large changes very slowly, skeptics can point to a wide range of concerns over the role of digital media. From a historical standpoint, opponents can single out the revolutionary predictions that were made at the advent of the radio and television era, which turned out to be overstated. However, more direct refutations are centered on the cost of implementing modern technology into the curriculum, which has the effect of giving wealthier institutions a large advantage with regard to access, as well as an advantage for individuals who have access at home. Teachers must be retrained, and assessment becomes more challenging, with cheating being hard to guard against. The inspirational effect that teachers can have is also mitigated as more of the teaching role is given to computers. Glenn [1] notes that easy access to mobile technology has increased the occurrence of plagiarism and cheating, and found that students have become more easily distracted.

As with all such arguments, the answer to how much technology should be used in the classroom will fall somewhere between the two extremes. There is evidence however that excessive use of technology on the part of faculty can lead to negative results. An attempt to use wiki technology (whereby an editable website is created by collaborating students) was described by Cole [2] as a "failed experiment", with no posts to the wiki during the first half of the semester. Students cited a lack of interest, a lack of time, and confusion with the technology as the main reasons for their failure to contribute. It is also possible that students were uncomfortable with the way that informal learning environments contrast with the formal relationship that students typically have with faculty. Selwyn [3] described how students disliked using Facebook for educational purposes, citing role conflict, given that "Facebook is used by many students as a space for contesting and resisting the asymmetrical power 
relationships built into the institutional offline positions of student and university system, therefore affording these students with backstage opportunities to be disruptive, challenging and resistant". The same issues regarding the blurring of social boundaries were alluded to by Boon and Sinclair [4], Madge et al. [5], and Anagnostopoulou et al. [6], with the latter concluding that "Although technology appears to be an integral part of students' lives, it does not seem to be an integral part of their learning lives."

This study considers the appropriate role of classroom technology, and provides insight from students who have experienced the educational system in both the United States, where the use of modern technology in the classroom is generally more widespread, and the United Kingdom, where the curriculum tends to be presented in a more traditional manner.

\section{Methodology}

Twelve students, who were given alphabetized pseudonyms, were interviewed during 2013 in order to gather the data. Six of these students were current exchange students from the United States studying in the United Kingdom, while the other six were United Kingdom students who had previously spent a semester or a full academic year studying in the United States. In order to gain perspectives from a wide range of academic disciplines, students from the natural sciences, the social sciences, and the humanities were selected to participate in the study.

Purposive sampling was used, and it was important to ensure that the students being interviewed were not all comparing undergraduate teaching in one country to a single university in the other. Therefore the participants were approached in a manner which attempted to gather viewpoints representing several different universities in the United Kingdom, along with several different types of institution in the United States. Care was also taken to ensure that a balance was maintained between the number of male and female participants. Two universities were used to collect the data, namely Keele University in England and the University of Central Florida, which were chosen based on the researcher's employment as a faculty member during the period in which the data were gathered. It should be noted that the students participating in the study combined to provide perspective from four institutions in each country.

The twelve participants all satisfied the criteria of being a current or former exchange student and having studied in the United States and the United Kingdom. All of the participants were aged between 20 and 22, with the British students being in their second or third year of study when travelling to the United States, and the American students being in their third or fourth year of study when travelling to the United Kingdom.

While prepared questions were used as the basis for the interviews, additional questions were asked when it was either felt that the original question was misinterpreted, or the answer that was given allowed further insight to be sought. No incentives were given to those participating in the study, with interviews typically lasting around 15 minutes, followed by a period during which the participants and the researcher chatted informally. All twelve of the students interviewed seemed very willing to give their time and answer all of the questions, often being apologetic if their limited experience meant they could not always provide a lengthy response.

\section{Results}

When asking the participants about the use of technology in undergraduate teaching, it was important to clarify the context given that it has become so prevalent that it is often taken for granted. My questions were therefore centered on three broad aspects of technology usage, namely how technology is used in traditional lecture-based classes, how technology is used as a medium for doing assignments (for example homework, group projects, or term papers), and finally how courses can be taught completely online, with little if any face-toface time with the instructor. If participants had firsthand experience of web-based courses they could obviously speak with greater familiarity, but since most of them did not, hypothetical questions were often resorted to regarding whether they would welcome taking courses of that nature. As a result, everyone was able to give me detailed feedback, and participants often gave both their own perceptions, as well as those of other students they had spoken with.

Almost everyone spoke positively when asked whether they like technology to be incorporated in the classroom. When Ivan was asked this question, he said:

Yes, of course, because it brings something new. You can improve yourself, and know how to use certain programs. I think it's quite interesting and valuable to have those skills in industry or in the future.

Diana answered in a similar manner, saying that:

I do [like technology to be used]. PowerPoint is really good. Going slowly through the slides is also good, and then putting them up on Blackboard afterwards. I like to read through what I've learned.

Diana's comment was in keeping with other participants who spoke with me about the benefits of 
lecture notes being uploaded to a university-wide database. While this seemed to be especially common in the United Kingdom, Eric was of the overall opinion that technology tends to be used less in the United Kingdom compared with the United States, though he did not view this as something negative:

In one of my psychology classes [in the UK] we used SPSS a lot, which I'd never used before. It was great. It was really hard to use, and confusing, but that's because I hate stats. On the whole I think technology is used less over here [in the UK], which is OK.

Felix also noticed that discipline specific software packages are prevalent in the United Kingdom:

Yes, especially in math. I think software is important. Actually, one of my classes [in the UK] used MATLAB for assignments.

Complaints about classroom technology were not common, and the use of PowerPoint seemed to be both ubiquitous and popular in classes taken by the participants. However, Grace spoke of how the monotony of going through slides can become annoying, and how students in the United Kingdom are less inclined to take notes directly from slides:

Yeah, I do like technology to be used, for visuals, but when it becomes predominately PowerPoint, slide after slide, you can't really pay attention. And that was also something different [in the UK], students were not constantly taking notes and writing from the slides, and that was cool because we could just listen, and we didn't have to vigorously take notes, because our teachers won't post the PowerPoint slides. So I could lose focus easily because I was constantly writing and then not listening to what they were saying.

Attitudes towards online homework were varied, but most of those interviewed were either wary or outright opposed to doing assignments online. The exception was Colin, who was very open to the idea of using different approaches:

I'm completely in favor of it. I do a lot of my learning out of textbooks, or just by doing research online, and so I don't think that the lectures are the be all and end all. I think there are a lot of ways to get to the same point.

Some participants, like Ivan, who was experiencing it for the first time, saw online assignments as an interesting novelty, though he added the caveat that he believed they need to be used in conjunction with written assignments rather than as a replacement:

I had my first experience of web-based learning here [in the US], where we did a project. We had to watch videos and then the teacher gave us a question. It was quite interesting. I think it has to be 50/50 to make sure it is balanced. It is good to have technology, you can learn new stuff, but sometimes it is better to write rather than typing.

Jessica was more enthusiastic about online assignments, noting how they seem to be more prevalent in the United States than the United Kingdom:

I think it depends on the class. I think that it helps a lot to have those programs to do individual homework problems, but [in the UK] we didn't have those individual homework assignments at all. However, if you're being independent you could still find similar things to keep up with the classes.

Eric did not object to using technology in order to complete assignments, but mentioned that he found the lack of consistency between different classes to be frustrating:

I like technology to be used, but would like it to be used more consistently. In one class, for politics, I had to turn everything in online and there was only one physical thing I had to turn in. In other classes you have to physically turn in everything and digital copies are just for verification. Because it's so inconsistent across all the different subjects, it is confusing.

Some participants strongly disliked online assignments, and preferred the traditional paper and pencil approach. Felix noted that:

I don't like online coursework as far as doing problems. I think they should be done on paper and turned in to the professor. As far as learning online, I have no problem with that.

Lee was of a similar mindset, but noted how there is an increasing use of online assignments:

No, I'm more old school. I'm just not a technology person myself, so I like things nice and simple, on paper. I hate it when you have to submit something online. It's a lot easier handwritten, hand it in, but I find it's becoming uniform, across the board, everything's going more with technology. 
Taking the use of technology to the extreme, participants were asked for their thoughts about classes taught completely online, where all the communication with faculty and other students occurs via the internet. Most of the students from the United Kingdom had no experience of such courses prior to studying in the United States, given that only the Open University promotes distance learning in the United Kingdom to any great extent (mostly to non-traditional age students). However, it was noticeable from the responses that participants from both countries viewed online classes negatively, with a range of academic and economic objections being cited. Grace described an online class in the United States she was taking, and mentioned how the reduced amount of learning made her feel as if she was not getting value for money from the class:

[Laughs before answering] I'm taking an online class now, where I don't see my teacher at all, and I don't really like it, because I don't really feel like I'm learning as much as I could. She's very open and I can ask her anything I want via e-mail, but I almost don't feel like I'm getting my money's worth. For these classes I'm paying so much and then I don't even have an interaction with a real professor. I do like real lectures because I feel I get more out of it.

Jessica was also dismissive of online courses, saying:

I know that at some of the large state schools there are entire courses that are online, and I would hate that! I think that would be very negative to my education.

Hazel was of a similar mindset, and while her response was brief, it seemed to encapsulate the general feeling:

\section{I like technology, but not for all of the course.}

Exchange students from the United Kingdom often shared their amazement with me that online courses even existed, and had difficulty in comprehending them. Ivan wondered how it was possible to prevent cheating, and questioned whether grades obtained in online courses had merit:

I am quite surprised, because here [in the US] some of my roommates have only online exams, online, online...For me if you are only doing online it's not your actual grade. You can open your book, read stuff, Google it. It is not $100 \%$ your grade, more like $50 \%$.
Lee gave a more balanced answer, but after stating how online courses might benefit him personally, he concluded by considering the extreme case in which all courses are online, stating how it would take away much of the university experience, and be akin to studying at the Open University in the United Kingdom:

I know business majors who don't have to go to class because they're all online. Personally, I prefer that because I don't like waking up early in the mornings. I can't concentrate that well in early lectures. And I'm quite an independent learner, so if I had an online class I could watch it by myself in the afternoon and evening, and understand far more than I would in the morning. So personally, I'm all for online lectures, but then it takes away the experience of attending lectures, and what's the point of the university then? You might as well stay at home and watch the lectures and save a lot more money, like the Open University in England.

\section{Discussion}

The data collected from the twelve participants back up the assertion by McCabe and Meuter [7] that "Today's students assume technology will be integral to their college experience". However, it is worth noting that the way in which students prefer technology to be integrated is simply through the use of PowerPoint slides during lectures and the subsequent uploading of lecture notes to the internet, rather than moving entire courses online. In this respect, the statement by Gregorian [8] that "Technology will supplement education, but will never replace the need for the residential university" is validated, as is the study by Milliken and Barnes [9], who found that a significant factor in their study showing a positive response by students to the use of classroom technology was simply due to the clarity of the (electronically written) lecture notes.

It appears that there is a law of diminishing returns in place, implying that students are in favor of classroom technology up to a certain point; however once technology is used to supplement rather than augment the role of the instructor, opinion becomes increasingly negative. This is in keeping with the findings of Diemer et al. [10], who noted that a moderate usage of technology is preferable both to using none at all or to an over usage. It should also be noted that the consistent opposition to classes taught entirely online cited by students in this study centered around the lack of classroom discussion and social interaction, as well as a sense that online classes do not offer the same value for money. This is consistent with previous 
studies, both by O'Malley and McGraw [11] and the National Union of Students [12].

\section{Conclusion}

While this study incorporates elements of many research areas, specifically exchange students, international students, and undergraduate teaching, it is unique in using exchange students as the lens for examining whether the perceptions of classroom technology prevalent in the research literature are shared by those who have studied in both countries. This issue is in keeping with the avenues for further research discussed by Bartram et al. [13], who concluded after gathering data from faculty regarding technology in the classroom that "It would also be interesting to include student perspectives, in an attempt to gain an understanding of the extent to which they corroborate or deviate from faculty perceptions."

This study also goes to the heart of a very important debate which will shape the future of higher education during the next generation. While much is made of the current generation of students, and their love of cell phones and tablet computers, White et al. [14] state that "educational technology in [UK] universities has not managed to match the ubiquity of technology in everyday life." Although this remark was referring specifically to technology usage in the United Kingdom, it also seems to apply to how students perceive the use of technology in the United States. The disconnect reinforced by this study is that while distance learning and online classes are generally touted as being in line with student wishes, and rarely portrayed as a necessary cost saving tool that allows administrators to do more with limited resources, there is evidence suggesting that the students want technology to be used in moderation in order to preserve the experience of attending a university, unless they have specific circumstances which preclude this option.

\section{References}

[1] Glenn, M., (2008, October), 'The future of higher education: How technology will shape learning', The Economist Intelligence Unit, pp. 1-27.

[2] Cole, M., (2009), 'Using Wiki technology to support student engagement: Lessons from the trenches', Computers \& Education, 52(1), pp. 141-146.

[3] Selwyn, N., (2009), 'Faceworking: Exploring students' education-related use of Facebook', Learning, Media and Technology, 34(2), pp. 157-174.

[4] Boon, S., and Sinclair, C., (2009), 'A world I don't inhabit: Disquiet and identity in Second Life and
Facebook', Educational Media International, 46(2), pp. 99-110.

[5] Madge, C., Meek, J., Wellens, J., and Hooley, T., (2009), 'Facebook, social integration and informal learning at university: It is more for socialising and talking to friends about work than for actually doing work', Learning, Media and Technology, 34(2), pp. 141-155.

[6] Anagnostopoulou, K., Parmar, D., and PriegoHernandez, J., (2009), 'An exploration of perceptions of learning and e-learning held by students who withdraw and those who persist with UK higher education', Brookes $e$ Journal of learning and teaching, 2(4).

[7] McCabe, D., and Meuter, M., (2011), 'A student view of technology in the classroom: Does it enhance the seven principles of good practice in undergraduate education?', Journal of Marketing Education 33(2), pp. 149-159.

[8] Gregorian, V., (2005), 'Six challenges to the American university'. In R. Hersh \& J. Merrow (Eds.), Declining by degrees. New York, NY: Palgrave MacMillan.

[9] Milliken, J., and Barnes, L., (2002), 'Teaching and technology in higher education: Student perceptions and personal reflections', Computers and Education, 39(3), pp. 223-235.

[10] Diemer, T., Fernandez, E., and Streepey, J., (2012), 'Student perceptions of classroom engagement and learning using iPads', Journal of Teaching and Learning with Technology, 1(2), pp. 13-25.

[11] O'Malley, J., and McCraw, H., (1999), 'Student perceptions of distance learning, online learning and the traditional classroom', Online Journal of Distance Learning Administration, 2(4), pp. 1-13.

[12] National Union of Students, (2010), Student perspectives on technology - demand, perceptions and training needs. Bristol, UK: HEFCE.

[13] Bartram, B., Brant, J., and Prowse, S., (2010), 'Embedding pedagogic innovations in higher education: a cross-faculty investigation of staff views at an English university', Education-Line, http://www.leeds.ac.uk/educol /documents/193686.pdf (accessed on 26 November, 2014).

[14] White, S., Davis, H., and Eales, S., (2007), 'Critical success factors for e-learning and institutional change some organisational perspectives on campus-wide elearning', British Journal of Educational Technology, 38(5), pp. 840-850. 